\title{
WORKPLACE SPIRITUALITY AND SOCIAL ENTERPRISE - A REVIEW AND RESEARCH AGENDA
}

\section{MUNKAHELYI SPIRITUALITÁS ÉS TÁRSADALMI VÁLLALKOZÁSOK - ÁTTEKINTÉS ÉS KUTATÁSI IRÁNYOK}

\begin{abstract}
Workplace spirituality is a social movement about purposeful work that has both personal and broader societal considerations. Social enterprises are alternative organizational forms that strive to create value by simultaneously pursuing social, economic and environmental goals. Both workplace spirituality and social enterprise discourses have a value creation orientation for self and others, framed as serving and contributing towards the common good. However, only a few studies have addressed the relevance of workplace spirituality for social enterprises. Based on the literature for workplace spirituality and social enterprise, respectively, this paper argues that these phenomena have a common ground: prosocial motives, doing well (value creation) and being well (flourishing). Workplace spirituality can help preserve social enterprises' integrity, while the social enterprise context can support the incorporation of workplace spirituality to generate positive outcomes. Further studies could explore this potentiality, and the present paper provides some future research suggestions.
\end{abstract}

Keywords: workplace spirituality, social enterprise, prosocial motives, value creation, well-being

A munkahelyi spiritualitás az elhivatott munkával foglalkozó társadalmi mozgalom, amely egyéni és társadalmi kérdéseket is felvet. A társadalmi vállalkozások olyan alternatív szervezeti formák, amelyek a társadalmi, gazdasági és környezeti célok egyidejű megvalósításával igyekeznek értéket teremteni. Mind a munkahelyi spiritualitással, mind a társadalmi vállalkozásokkal foglalkozó szakirodalmi diskurzusra jellemző az értékteremtő elköteleződés, amelyet szolgálatként és a közjóhoz való hozzájárulásként értelmeznek. Azonban csak néhány tanulmány foglalkozott a munkahelyi spiritualitás társadalmi vállalkozásokban betöltött szerepével. A munkahelyi spiritualitás és a társadalmi vállalkozások irodalma alapján ez a cikk amellett érvel, hogy e jelenségek közös nevezőjét a proszociális indíttatás jelenti, vagyis a jót tét (értékteremtés) és a jól lét (gyarapodás). A munkahelyi spiritualitás segítheti a társadalmi vállalkozások integritásának megőrzését, míg a társadalmi vállalkozások kontextusa támogathatja a pozitív eredményeket teremtő munkahelyi spiritualitás kibontakoztatását. E lehetőség feltárása érdekében további kutatások elvégzése szükséges, amelyek irányára jelen tanulmány is javaslatot tesz.

Kulcsszavak: munkahelyi spiritualitás, társadalmi vállalkozás, proszociális indíttatás, értékteremtés, jóllét

\section{Funding/Finanszírozás:}

The author is grateful to the editor of this journal, Henriett Primecz, for their invaluable guidance and support. The author also wishes to thank the two anonymous reviewers for their helpful suggestions and critique of an earlier version of this paper. The author also acknowledges the funding support for proofreading this paper, received from project no. EFOP3.6.2-16-2017-00007, titled "Aspects on the development of intelligent, sustainable and inclusive society: social, technological, innovation networks in employment and digital economy". The project has been supported by the European Union and co-financed by the European Social Fund and the budget of Hungary.

A szerző hálás a folyóirat szerkesztőjének, Primecz Henriettnek felbecsülhetetlen útmutatásáért és támogatásáért. A szerző köszönetet kíván mondani a két névtelen bírálónak hasznos javaslataikért és a cikk korábbi változatának kritikájáért. A szerző köszönetet mond a cikk korrektúrájának finanszírozásához nyújtott támogatásért is, amelyet az EFOP-3.6.2-162017-00007, „Az intelligens, fenntartható és befogadó társadalom fejlődésének szempontjai: szociális, technológiai, innovációs hálózatok a foglalkoztatásban és a digitális gazdaságban" projekt nyújtott. A projektet az Európai Unió támogatta és az Európai Szociális Alap, valamint Magyarország költségvetése társfinanszírozta.

\section{Author/Szerző:}

Natasha Gjorevska, PhD student, Corvinus University of Budapest, (gjorevska.natasha@uni-corvinus.hu)

This article was received: 28. 09. 2020, revised: 11. 02. 2021, accepted: 02. 03. 2021.

A cikk beérkezett: 2020. 09. 28-án, javítva: 2021. 02. 11-én, elfogadva: 2021. 03. 02-án. 
$\mathrm{T}_{\mathrm{b}}$ he functioning of organizations within society and the broader environment is taking a turn towards making a positive social and environmental impact by confronting pressing issues through socially responsible and ethical products and services. The relationship between enterprises (and entrepreneurs) and society and the environment is changing, and organizations are increasingly pressured to attempt to address the world's existing sustainability problems and challenges. As a result, there has been a rise in alternative organizations because of their potential for balancing economic performance with achieving social goals. These alternative forms of organizing are known as the third sector, and include social enterprises, hybrid organizations or cooperatives, which strive to find new ways of influencing social and economic development.

This shift towards social enterprises has occurred as a response to so-called 'wicked' problems and grand challenges, such as ecological sustainability, climate change, social cohesion and food insecurity, which require alternative ways to make the world a better place (see Barney et al., 2015). This process of transformation has resulted in heightened consciousness, interrelated awareness and engagement in other-focused actions, which has in turn led to the rise in social enterprises as mutually co-creative shared value partnerships. Scholars have concurrently started to introduce and emphasize the relevance of spirituality for socially responsible entrepreneurship (e.g. Kauanui et al., 2010; Sullivan Mort et al., 2003; Ungvári-Zrínyi, 2014). More broadly, a spiritually informed perspective is seen as beneficial for the fields of management and organizational behaviour because of its potential for humanizing organizational life (Lavine et al., 2014). Although the relevance of spirituality for organizations has been recognized, the focus has predominantly been on large corporations and corporate leaders (Carette \& King, 2005; Washington, 2016, in: Driscoll et al., 2019, p. 155-156).

While there have been calls for incorporating spirituality in organizational (especially corporate) life as a measure against exploitative practices, there is a body of critical work on workplace spirituality that questions its beneficial nature in the work context. For instance, Bell and Taylor (2003, p. 332) argue that, paradoxically, in aiming to warrant 'liberation from the constraints of work', workplace spirituality perpetuates these constraints by resulting in more exploitation in the name of fulfilling work. Likewise, other scholars warn against appropriation of performative workplace spirituality to harness economic goals, thus forcing spirituality to serve as a managerial/organizational tool to exploit employee resources (see Case \& Gosling, 2010; Lips-Wiersma et al., 2009; Long \& Driscoll, 2015; McKee et al., 2008; Oswick, 2009).

There has, however, been little research on workplace spirituality in alternative organizational forms such as social enterprises, where the intra-organizational structure, processes and ownership aspects usually stand in contrast to conventional management practices of hierarchy and control. Such an alternative context offers the possibility of disalienated work (Kociatkiewicz et al., 2020), which aligns with the spiritual perspective of self-work integration in which workers have autonomy and control over their work domain. This opens a promising area of research on workplace spirituality and its potential (mis) use in the social enterprise context. To bring forth the relevance of spirituality for alternative organizational forms, and vice versa, the present paper discusses the connection between workplace spirituality and social enterprise.

The remainder of this paper is organized as follows. First, the main conceptualizations and critical aspects of workplace spirituality are presented. This is followed by an overview of social enterprise and its connection to spirituality. Next the methodology is presented. Then, the mutual characteristics between workplace spirituality and social enterprise are discussed - that is, prosocial motives, doing well, and being well. The paper concludes with a summary and a call for future research on workplace spirituality in social enterprises.

\section{Workplace spirituality}

Spirituality is a rich, intercultural and multi-layered concept, which can mean different things to different people. Spirituality is characterized as both personal and universal (Bouckaert \& Zsolnai, 2012; Mitroff, 2003). In general, spirituality can be understood as a 'reconnection to the inner self, a search for universal values beyond egocentric strivings, deep empathy with all living beings, and transcendence' (Bouckaert \& Zsolnai, 2012, p. 491). Although spirituality is historically rooted in religion, its current use in business is often not associated with any specific religious tradition (Korac-Kakabadse et al., 2002) and even goes beyond the boundaries of institutional religions (Bouckaert \& Zsolnai, 2012). Thus, management and organizational scholars have called for a distinction between spirituality at work and religion at work (e.g. Ashmos \& Duchon, 2000; Bouckaert \& Zsolnai, 2012; Korac-Kakabadse et al., 2002; Mitroff, 2003), noting that spirituality is a broader term that can encompass but also advance beyond religion. This paper follows this approach.

Within the domain of work, the interest in spirituality has been welcomed from the 1970s (see Oswick, 2009) and has rapidly increased in the field of management for the last two decades (Houghton et al., 2016; McKee et al., 2008; Oswick, 2009), with the first major study conducted in the 1990s in the corporate context (see Mitroff \& Denton, 1999). Like spirituality in general, there is a lack of consensus about the meaning of workplace spirituality, although these terms have been used somewhat interchangeably in the management and organizational research. Workplace spirituality, however, is a narrower term than spirituality and here refers to the expression of spiritual values and beliefs in the work sphere, which invites a plethora of interpretations. As Case and Gosling (2010, p. 263) have noted, workplace spirituality is 'an ephemeral phenomenon approachable from multiple perspectives'.

Based on the literature, several common dimensions of workplace spirituality can be identified that relate to an individual's characteristics or motives, behaviours and 
experiences. These can include, for example, connection, compassion, mindfulness, meaningful work, transcendence, interconnectedness, a sense of mission and purpose, a sense of wholeness or a holistic mindset, doing work with broader societal implications, purpose beyond one's self, a sense of calling, eudaimonia and well-being (see Dik \& Duffy, 2009; Dolan \& Altman, 2012; Duffy \& Dik, 2013; Fry, 2003; Guillén et al., 2015; Jurkiewicz \& Giacalone, 2004; Mitroff \& Denton, 1999; Pawar, 2008; Sendjaya, 2007; Sheep, 2006; Van Dierendonck \& Mohan, 2006; Wills, 2009). Ashmos and Duchon (2000, p. 137) provide a three-dimensional framework for spirituality - inner life, meaning and purpose in work, a sense of connection and community - and define workplace spirituality as 'the recognition that employees have an inner life that nourishes and is nourished by meaningful work that takes place in the context of community'. According to Krishnakumar and Neck (2002, p. 154-156), the perspectives on spirituality can be categorized within three positions: the intrinsic-origin view (originating from within, inner consciousness, beliefs and values); the religious view; and the existentialist view (search for meaningful work). The conceptualization of Krishnakumar and Neck (2002) is similar to that of Ashmos and Duchon (2000), although the former advanced a religious perspective to workplace spirituality. The intrinsic-origin view corresponds to the inner life and community dimensions, and the existentialist view is consistent with the meaningful work dimension.

Jurkiewicz and Giacalone (2004, p. 129) define workplace spirituality as 'a framework of organizational values evidenced in the culture that promote employees' experience of transcendence through the work process, facilitating their sense of being connected to others in a way that provides feelings of completeness and joy'. According to Lips-Wiersma et al. (2009), the central notion of workplace spirituality is bringing the physical, intellectual, emotional and spiritual dimensions of the person to the workplace. Sheep (2006, p. 360), meanwhile, offers a convergent definition of workplace spirituality, based on the following four common dimensions:

1. self-workplace integration (a holistic approach to workplace and self, and a personal desire to bring the whole being into work),

2. meaning in work (of the work itself, rather than the work environment),

3. transcendence of self (rising above self to become part of an interconnected whole), and

4. growth / development of one's inner self at work.

In an effort to provide an inclusive framework, Houghton et al. (2016) update and expand the original conceptualizations of Krishnakumar and Neck (2002). Citing various sources, Houghton et al. (2016) suggest that, despite previous concerns about the lack of focused approach to workplace spirituality, definitions of this concept have revolved around the three dimensions originally provided by Ashmos and Duchon (2002), which can serve as a basis for a common definition. The categorization of Krishna- kumar and Neck (2002) further contributed to a focalization around the key ideas of consciousness, connectedness and meaning and purpose at work (Houghton et al., 2016). They further note (p. 181) that workplace spirituality can be conceptualized at the individual level (e.g. perceptions of inner life, meaningful and purposeful work, and a sense of community and connectedness); group level (e.g. sense of community); and as an organization-level phenomenon (e.g. spiritual climate or culture as reflected in the organization's values, vision and purpose).

A more recent work on workplace spirituality, described as self-spirituality (Zaidman, 2019), proposes spirituality at work as a radical equality approach to workplace relations and an alternative to the masculine secular organizations, thereby providing a gender-based critique of workplace spirituality. Self-spirituality, according to Zaidman (2019), has the potential for developing relationships based on cooperation, in opposition to secular masculine organizations, thus causing objections and discomfort. This author criticizes masculine ways of knowing and organizing such as rationality, patriarchy and competition, arguing for the acceptance of a more feminine mode of feelings into organizations. Zaidman (2019) suggests that 'feminine' modes of incorporating spirituality into organizations do not allow domestication for masculine, rational or utilitarian purposes of control and dominance and thus, these modes correct for the potential misuse of workplace spirituality.

Overall, workplace spirituality is seen by its advocates as a new paradigm in the field of management and organizations - referred to as 'the spirituality movement' - that focuses on understanding employees' spiritual needs and search for meaning (Guillén et al., 2015; Karakas \& Sarigollu, 2013, p. 667) and includes expressions of one's spirituality at work with societal considerations (Sheep, 2006). Nurturing and developing one's spiritual side means offering a source of strength, both on and off the job, and at the same time helping employees to develop, which consequently results in making the workplace a stronger, safer and much saner place to do business (Korac-Kakabadse et al., 2002). Success from a spiritual perspective is about a sense of accomplishment, a balance of work and family, and contributions to both society and to employees (Ashar \& Lane-Maher, 2004). This very much connects to the perspective of social entrepreneurship and its goals.

However, other scholars have asserted that spirituality at work is not a new discourse and have provided a more critical outlook on workplace spirituality (e.g. Bell \& Taylor, 2003; Case \& Gosling, 2010; Long \& Driscoll, 2015). For instance, Long and Driscoll (2015) posit that workplace spirituality emerged by borrowing from other organizational studies discourses, while Bell and Taylor (2003) argue that the intent and practices of workplace spirituality are not novel - rather, organizations and spirituality have a long and complex history, particularly rooted in the Protestant values that gave rise to the capitalist work ethic. These authors refer to the work of Weber and Foucault to provide a perspective on the centrality of reli- 
gion and spirituality in modern day work and disciplinary practice, which can be appropriated by managers as a tool for obedience and a 'source of pastoral power' (Bell \& Taylor, 2003, p. 340-342) to encourage employees' willing compliance in the spiritual organization (Case \& Gosling, 2010). This can refer to utilizing spirituality as an organizational resource for fostering employee performance, a source of meaning in whatever work conditions and as a tool to mobilize a process of internalizing the organization's aims and thus, colonizing the self through uncritical service to the organization's interests - all of which, ironically, goes against spirituality's aim of emancipation and eradication of dehumanizing practices.

Similarly, Long and Driscoll (2015) question whether workplace spirituality can offer solutions to organizational issues when it is not a new phenomenon in organizations. These authors' analysis shows that workplace spirituality borrows from organizational discourses, such as positive organizational scholarship (POS), human relations movement, diversity management, leadership and corporate social responsibility (CSR), and carries the same limitations to bring forth ideas about collaboration, participation, inclusion and responsibility to others as valuable goals in and for themselves, beyond being just part of a manager's toolkit. Consequently, the main criticism of workplace spirituality is that spirituality assumes an apolitical and non-controlled organizational context, which creates tensions between releasing or managing spirituality in organizations, emphasizes individual rather than structural level change and works within the current capitalist institutions and economic system rather than challenging it to bring about social change (Bell \& Taylor, 2003; Long \& Driscoll, 2015). This criticism is concerned with the prevailing individualizing tendencies of the workplace spirituality discourse rooted in Western individualistic logic that focuses on self-improvement and prosperity (enlightened self-interest), which do not question or disrupt the systemic business foundations, which are by nature regressive.

Thus, workplace spirituality is perceived as both a novel and an existing discourse within organizations that can be progressive or alienating and enable both individualizing and totalizing use of power; the latter leading to 'the engineering of the human soul' (Rose, 1990; Townley, 1994, in: Bell \& Taylor, 2003, p. 342). Nevertheless, it is possible for workplace spirituality to support 'complementary personal and organizational transformation' (Bell \& Taylor, 2003, p. 345), to promote cooperation and compassion and improve the state of workers and work, provided spirituality engages with business and societal level discourses for genuine improvement of work-life conditions (see Long \& Driscoll, 2015). In trying to address the debate between instrumentality and ethicality, Sheep (2006) suggests a person-organization fit where workplace spirituality is driven by a worker's preferences to achieve both individual and organizational development, as well as taking a multiparadigm approach in which no one concern or perspective (individual-organization-society) is privileged over another. This paper proposes that an alternative organizational discourse such as social entrepreneurship may be relevant to the discussion of workplace spirituality, as it centres on ideas for alternative ways of organizing founded on inclusion, democratic participation and prioritizing human and planetary interests over economic ones.

\section{Social enterprise}

The term social enterprise is used as a broad umbrella for different alternative organizational forms and activities that create social value by providing solutions to social problems. Social entrepreneurship is the process through which a social enterprise is created, and this form of entrepreneurship is viewed as a simultaneous pursuit of social, economic and environmental goals that stems from the interplay of general, mutual and capital interests (Defourny \& Nyssens, 2017). This definition encompasses both for-profit and non-profit enterprises, with most of the focus being on non-profits and the creation of social value over economic value (Austin et al., 2006; Dacin et al., 2010; Dees, 1998; Mair \& Marti, 2006; Peredo \& McLean, 2006, in: Tiba et al., 2018, p. 266; Zahra et al., 2009). According to Teasdale (2012, p. 101), the distinction between social enterprises and other forms of organizations is based on two dimensions: the relative adherence to social or economic goals, and the degree of democratic control and ownership. Teasdale (2012) concludes that the similarity in all of the definitions of social enterprises is the primacy of social aims and the centrality of trading; however, different authors use the term to label different organizational types and practices.

Scholars have argued that the social enterprise is not a new organizational form and that it 'encompasses a large range of organizations evolving from earlier forms of non-profit, co-operative and mainstream business' (Teasdale, 2012, p. 100). Many of these organizational forms have existed for centuries, but the current discourse in academia uses new language for describing them (Defourny $\&$ Nyssens, 2010). For example, the neo-liberal discourse promotes businesses as powerful means for achieving social change, which resulted in the construction of a narrative of social enterprises (Dey \& Steyaert, 2010). The construction of social enterprises is ongoing and there are competing narratives about what a social enterprise is.

Social entrepreneurship is usually defined as an entrepreneurial activity found in the non-profit, business and governmental sectors to create social value (Austin et al., 2006) and usually targeting local problems with global relevance (Santos, 2012). Santos (2012) develops a positive theory of social entrepreneurship to avoid normative classification on what is social or not and focuses on value creation. In this view, social entrepreneurs are primarily motivated by creating value for society, instead of capturing value, as commercial entrepreneurs do. This focus differentiates social entrepreneurs by how they act: (1) they aim to achieve a sustainable solution (rather than a competitive advantage) and (2) they have a logic of empowerment (instead of control) concerning internal and external organizational stakeholders (Santos, 2012, p. 345). 
Kay et al. (2016) propose an alternative conceptual framework for social enterprises and suggest that social enterprise activities should work towards social, environmental and societal impacts while using economic activities as a means to achieve these results. This challenges the commonly addressed triple bottom line (social, environmental, economic) and replaces the economic with a societal impact. Societal impact is about the relationships between individuals and groups, and in this sense, it is distinct from social impact, which is an impact on individuals and groups but not on the relationships between them (see Kay et al., 2016). Societal impact is about prosperity and relationships, and the economic aspect only helps to support this goal, but is not an end goal in and for itself. Advancing the motivational aspects in various forms of social enterprises, Bull and Ridley-Duff (2019) develop a comprehensive framework that explains the underlying moral reasoning behind different orientations of social enterprises ranging from the altruistic or philanthropic to commercial endeavours.

It is thus possible that socially oriented entrepreneurial activities - such as improving the living conditions of communities, societal development or care for the environment - can be spiritually motivated. However, this is not to say that all social enterprises are simultaneously spiritual enterprises. The two can be mutually reinforcing but not necessarily related. In this vein, Ungvári-Zrínyi (2014) emphasizes the importance of spirituality for socially and environmentally responsible entrepreneurship and has stated that organizations should not be considered as money-producing machines, but rather as communities that produce social values and positive outcomes for people and society. The common spiritual themes that relate to entrepreneurship include meaning and purpose, living an integrated life, experiencing inner life and being in community with others (see Kauanui et al., 2010). According to Sullivan Mort et al. (2003), the spiritual or virtue aspect is an important dimension of social entrepreneurship, which distinguishes social from commercial enterprises. Virtues such as compassion, empathy and honesty are characteristic of social enterprise endeavours that aim to make a meaningful contribution to socioeconomic development (Sullivan Mort et al., 2003).

Following Santos' (2012) positive theory of social entrepreneurship, this paper proposes that the need for social value creation can be aligned with spiritually driven motives (doing good for others) and suggests a complementary perspective between spirituality at work and social enterprise. Social enterprises are an example of balancing between commercial logic and the logic of social purpose, with a focus on the latter. This does not mean that there is a trade-off between these goals, because they may be simultaneously achieved; rather, it implies that the emphasis is on shared values and outcomes, instead of solely personal gains. This aligns with the spiritual outlook to work orientation, and this mutuality is addressed next.

\section{Methodology}

This paper is based on a review of the workplace spirituality and social enterprise literatures. A narrative literature review was conducted to present a broad overview of the topics investigated and to present perspectives that could stimulate further scholarly dialogues and provide guidance for future research endeavours (see Green et al., 2006). Narrative reviews are not a form of evidence; rather, they are useful for developing new ways of thinking about certain phenomena. The first step in this kind of review is to identify whether there is any published material on the topic to establish the need for such contributions. Therefore, a preliminary search of the literature on workplace spirituality and social enterprise was conducted, which showed that there are no articles published that address the connection between the two phenomena and the existing studies are inadequate to answer the question fully. Thus, the contribution of this review is to illuminate the potential of connecting workplace spirituality and social enterprise and to set forth a research agenda.

The literature search on both workplace spirituality and social enterprise was conducted by using the following databases: EBSCOhost Business Source Premier, Emerald Insight, Sage journals, Springer, Taylor \& Francis Online, Wiley Online Library and ScienceDirect. Relevant journal articles were searched using the words 'workplace spirituality' or 'spirituality' and 'social enterprise' in title/abstract/keywords and, alternatively, with either of the term appearing anywhere, when the search for both terms in the title/abstract/keywords produced zero results (see the Appendix). The results that appeared in the databases were filtered based on the criteria explained below.

Publications that did not mention (workplace) spirituality or social enterprise, or both, in either the title, abstract or keywords were excluded. The resulting articles were checked for the topics and questions they addressed and were assessed based on their suitability to be included in this review. For instance, a word search was performed within each publication to assess the relevance of spirituality in a social enterprise publication or social enterprise in a spirituality publication. The publications that had only a few mentions of spirituality and/or social enterprise (i.e. under five) within the body of the text were also excluded from this review.

Upon filtering the articles, only a few publications fitted the search criteria in terms of addressing both spirituality at work and social entrepreneurship sufficiently as core research theme/s. These publications do not explore the conceptual connection between the two fields, but rather provide evidence about specific spiritual (religious) principles or practices and the contexts of social enterprise. For instance, the case study of Haskel et al. (2012) describes an Egyptian caregiving social enterprise that illustrates the integration of spiritual and religious inspired values for community transformation and social impact. Waddock and Steckler (2013) illuminate how social entrepreneurs are guided by purpose and how they can engage in spiritual practices through retreats as spiritual spaces 
for inspiration and connection. Gamble and Beer (2017) examine performance measurement in non-profits informed by Buddhist spiritual practices and identify three essential principles. Finally, Gjorevska (2019) theorizes about spiritually informed motives for engaging in social enterprise endeavours.

The abovementioned publications were not sufficient for exploring the key features that connect workplace spirituality and social entrepreneurship, so additional publications were identified from review papers on each topic. For workplace spirituality, several databases were searched (EBSCOhost including Business Source Premier, Emerald Insight, Springer, Sage Journals, ScienceDirect, Taylor \& Francis Online and Wiley Online Library) using the following keywords: 'workplace spirituality' (in title) and 'review'. The initial selection began with peer-reviewed articles in English, some of which appeared in the search results across several databases. These articles were used as a starting point in the analysis of workplace spirituality. For instance, Houghton et al. (2016) appeared in almost all of database search results; the following articles appeared in more than one or two databases: Vasconcelos (2018), Long and Driscoll (2015), Case and Gosling (2010), Oswick (2009), Pawar (2009) and Sheep (2006). Following this, works referenced in these publications were explored. The publications used as a starting point for the social enterprise literature were articles from renowned authors in this field that addressed the typology and discourse of social enterprise, such as Defourny and Nyssens (2017), Teasdale (2012) and Santos (2012).

\section{Workplace spirituality and social enterprise}

Both workplace spirituality and social enterprise are multifaceted and fluid phenomena that lack a clear or overarching definition, and both perhaps should not be simplified to one single definition. This opens possibilities for further investigation into our understanding of these concepts and their interrelation. While there are a relatively solid number of articles about (workplace) spirituality and social enterprise, respectively, the studies on the connection between them are limited. Regarding entrepreneurship in general, Kauanui et al. (2010) provide evidence of spiritually driven motives among entrepreneurs, while Balog et al. (2014) show that there is a rich connection between entrepreneurship and spirituality. The study of spirituality within the entrepreneurial context shifted from macro-level outcomes (firm performance) in the 1980s to more micro-level outcomes (motives, well-being) in the mid-2000s (see Balog et al., 2014). With respect to spirituality in the social enterprise context, the existing studies have mainly focused on leadership perspectives and motivational aspects (e.g. Miller et al., 2012; Ungvári-Zrínyi, 2014). Thus, there is still little evidence about the intersection between workplace spirituality and social enterprise, and more studies are needed to examine the potential of bridging these phenomena.

Within the literature, there are perspectives on the dark side of workplace spirituality (e.g. Ashforth \& Pratt, 2003;
Case \& Gosling, 2010; Lips-Wiersma et al., 2009; McKee et al., 2008) and on the dark side of social entrepreneurship (e.g. Chell et al., 2016; Dacin et al., 2011; Talmage et al., 2019), albeit without consideration of both phenomena jointly. Like workplace spirituality, the critical issues with respect to social entrepreneurship involve exploitation for private gain, corrupt use of resources, mission drift or failure (see Talmage et al., 2019, p. 135). Nevertheless, workplace spirituality and social enterprises have the potential to expose and find alternatives to existing socioeconomic inequalities to improve the conditions of work workers and society. Therefore, this paper focuses on the common ground between workplace spirituality and social entrepreneurship that is potentially generative of positive outcomes for workers, members of society and beyond (e.g. the natural world). The proposition of this paper is that workplace spirituality has the capacity to support the social value orientation of social enterprises and prevent them from falling into exploitative practices for material gains, while social enterprises can in turn, correct for the potential misuse of spirituality that could result in disregarding the material conditions.

On the one hand, workplace spirituality could be a corrective measure to restore balance between the material and non-material aspects, provided it is practised to make genuine improvements to work and social conditions, with democratic engagement of stakeholders and accountable management (as outlined by Long \& Driscoll, 2015, p. 959). In this way, workplace spirituality can prevent social enterprises from reverting to prioritizing economic goals and competitiveness. This comes from the possibility that the 'social' in social entrepreneurship is not necessarily inherently ethical, and that during challenging circumstances, social entrepreneurs may be prone to mission drift (e.g. Chell et al., 2016). Dacin et al. (2011), for example, warn about the danger of privileging the achievement of economic goals (revenue) to the point of neglecting social value creation or making it symbolic solely to serve economic goals. Incorporating spirituality at work can support alternative ways of organizing based on cooperation and mutuality, rather than competition and utilitarianism (see Zaidman, 2019), which maintains a focus on value creation for self and others and, thus, helps sustain the social enterprise's purpose. For instance, Gamble and Beer (2017) show that not-for-profit social enterprises that integrate spiritual practices (individual/organizational awareness, connectedness and higher meaning) can mitigate the overemphasis on profit in performance management. Engaging in spiritual activities, such as reflective practices, can 'generate self-, other- and system- awareness' that can support commitment to social change by allowing individuals to become aware of and connected to a bigger set of issues in the broader system (Waddock \& Steckler, 2013, p. 297). Furthermore, the integration of (spiritual or religious) values can support engagement in social enterprise activities and sustain commitment to community transformation and development (see Haskel et al., 2012).

On the other hand, the social entrepreneurship context could provide a workplace spirituality practice that 
accounts for material and work environment factors. This is because of the danger of spiritual symbolism that could result in organizations taking advantage of workers and co-opting them to endure adverse working conditions, as some scholars have warned (see Ashforth \& Pratt, 2003; Bell \& Taylor, 2003; Case \& Gosling, 2010; Long \& Driscoll, 2015; May et al., 2004; McKee et al., 2008). Social entrepreneurship could be a corrective measure in such cases, as alternative organizational forms tend to be based on the principles of democratic control and decision-making, solidarity and responsibility (see e.g. Parker et al., 2014; Pearce, 1994; Teasdale, 2012). For instance, alternative organizations such as cooperatives provide workspaces that are worker controlled and owned, which enables disalienation or 'being at home' at work (see Kociatkiewicz et al., 2020). In this way, within the context of social enterprises, workplace spirituality and social entrepreneurship can have a complementary, mutually reinforcing relationship, which may be a promising avenue for future studies.

The underlying beliefs that have led to the emergence of social enterprises are similar to those of organizational spirituality and illustrate a paradigm shift from the understanding of businesses as primarily serving their commercial interests. This is due to the realization that businesses do not operate in isolation from the society they are part of, which brings the prosocial orientation to the fore. Social enterprises give primacy to social purpose before profit (Teasdale, 2012) and to value creation for stakeholders before shareholders (Santos, 2012). Social entrepreneurship has gained momentum for its ethically, socially inclusive and responsible ways of producing goods and services (e.g. Kay et al., 2016). Similarly, the literature on spiritual motives in the workplace suggests that spiritual individuals prioritize value creation over value capture (Kauanui et al., 2010); aim to contribute to society (Fry, 2003); care for multiple stakeholders (Avolio et al., 2004, Benefiel, 2005; Fry, 2003; Reave, 2005; Stone et al., 2004; Zsolnai, 2011); and consider the quality of their organization's products (Pruzan, 2008). Considering that most research around workplace spirituality centres on motives, (leadership) behaviours and organizational and/or individual outcomes, these common aspects of workplace spirituality are com- pared to similar themes in social entrepreneurship and grouped into motives, practices and well-being outcomes (see Table 1).

In terms of motives, both workplace spirituality and social entrepreneurship encompass prosocial or other-oriented motives that support the goal of giving to others by feeling a unity or interconnection. In terms of practices, both phenomena are focused on doing well for others and self, doing good in and for itself, contributing to the greater good and looking beyond immediate self-interest, which supports purpose orientation and value creation. With respect to well-being, both workplace spirituality and social entrepreneurship not only contribute to experiencing heightened form of well-being, but also a more meaningful and long-lasting one (flourishing), which comes from service to others and meaningful work, and both seek to maximize well-being for all stakeholders, or as many as possible. These common aspects are addressed in the following sections.

\section{Prosocial (other-oriented) motives}

This aspect refers to individual entrepreneurs' and workers' motives for work and engaging in social enterprises. Within the domain of (workplace) spirituality, motivational aspects are addressed as in a self-transcendent, other-focused orientation to work (e.g. Ashmos \& Duchon, 2000; Guillén et al., 2015; Koltko-Rivera, 2006; Mitroff \& Denton, 1999; Tongo, 2016). The basic assumption of the spirituality movement is that human beings are not driven solely by self-interest (intrinsic and extrinsic motives), but also by others-interest - that is, humans have transcendent motives (Guillén et al., 2015). The essence of transcendent or prosocial work motivation lies in a spiritually induced process, driven by a selfless need to improve the lives of employees, the community, society and the environment (Guillén et al., 2015; Sheep, 2006; Tongo, 2016; Ungvári-Zrínyi, 2014). The spiritual motivation in the workplace is thus based on the idea of connecting to others, a sense of holism (e.g. Ashmos \& Duchon, 2000; Mitroff \& Denton, 1999) and seeing work as a calling (broadly defined as a sense of purpose beyond the self; Fry, 2003) that has primarily other-oriented motives to help or advance others in some way (Dik \& Duffy, 2009; Duffy \& Dik, 2013).

\section{Common aspects of workplace spirituality and social entrepreneurship}

Table 1

\begin{tabular}{|l|l|l|l|}
\hline & \multicolumn{1}{|c|}{ Workplace spirituality } & \multicolumn{1}{c|}{ Social entrepreneurship } & Common aspects \\
\hline Motives & $\begin{array}{l}\text { Compassion; prosocial/ transcendental } \\
\text { motivation; interconnectedness; a sense of } \\
\text { mission/purpose/calling; holism }\end{array}$ & $\begin{array}{l}\text { Prosocial orientation; other-regarding; } \\
\text { compassion; holistic mindset; inclusiveness }\end{array}$ & Prosocial motives \\
\hline $\begin{array}{l}\text { Practices/ } \\
\text { behaviours }\end{array}$ & $\begin{array}{l}\text { Common good - doing work with broader } \\
\text { societal implications; purpose beyond one's } \\
\text { self; cooperation; meaningful work }\end{array}$ & $\begin{array}{l}\text { Value creation - social, societal, } \\
\text { environmental, economic; achieving } \\
\text { sustainable solution; meaningful contribution; } \\
\text { cooperation }\end{array}$ & $\begin{array}{l}\text { Doing well(value } \\
\text { creation) }\end{array}$ \\
\hline $\begin{array}{l}\text { Outcomes/ } \\
\text { experiences }\end{array}$ & Eudaimonia; well-being; flourishing & Empowerment; multi-stakeholder well-being & $\begin{array}{l}\text { Being well } \\
\text { (flourishing) }\end{array}$ \\
\hline
\end{tabular}

Source: own research 
Within the field of social entrepreneurship, similar notions of other-orientation have been expressed. For instance, Santos (2012, p. 349) challenges the divisive distinction between 'self-interest' and 'other-regarding' behaviour and states that there is growing evidence 'of economic actors that behave as if motivated by a regard for others (creating social enterprises, volunteering in charities, and pursuing social missions in their organizations)'. Kauanui et al. (2010) provide evidence of a prosocial, spiritual motivation among entrepreneurs, labelled as 'make me whole', albeit not solely among social entrepreneurs, which supports the presence of spiritual motives in entrepreneurship. Bull and Ridley-Duff (2019) develop a motivational matrix in social enterprise business models that distinguishes between who directs the activities (self-directed or directed by others) and who benefits (the self or others). Depending on the specific social enterprise form, the activities can be motivated by prosocial, mutualized (reciprocal) and individualized outcomes. This framework helps explain how motivations in social enterprise drive individual and/or collective action, as well as the response to social challenges.

Prosocial motivation thus appears to be a common aspect in workplace spirituality and social enterprise. However, more research evidence is needed to explore the role of spirituality in maintaining prosocial orientation, especially during challenges, as well as whether a social enterprise setting (and what kind) can sustain a spiritual workplace in times of crisis. Would there be a difference or change in motives between stable and challenging times? These are some questions that could be explored further regarding the motivational aspects of spirituality in social enterprises.

\section{Doing well (value creation)}

This aspect can be linked to individual, group and organizational level practices. This perspective is about doing what is good for the sake of doing it, for itself. The same perspective translated into organizational contexts means creating more 'relational goods' than 'positional goods', which comes down to helping one another instead of competing at and through work. As a result, discovering and constructing the self through work is becoming more important than advancing the self in the organization, which explains the increase in organizational spirituality and social enterprise initiatives.

Within the workplace spirituality discourse, Benefiel (2005) provides an example of a spiritual journey for individuals and organizations and shows that spirituality at work involves giving to and serving others even when it does not seem profitable or convenient. This account resembles social entrepreneurship's primacy of social service over economic gains. Within the social enterprise discourse, scholars have conceptualized a social enterprise as an economic activity that seeks to maximize well-being for all (see Kay et al., 2016), which resembles the spiritual perspective of giving to others. Kay et al. (2016) also suggest that social enterprise can and should contribute to individual and community well-being. Value creation, community service or serving the common good (framed here as doing well) are topics present in both the workplace spirituality (e.g. Bouckaert \& Zsolnai, 2012; Fry, 2003; Sheep, 2006; Ungvári-Zrínyi, 2014) and in the social enterprise literatures (e.g. Defourny \& Nyssens, 2017; Kay et al., 2016; Santos, 2012).

A promising avenue for future research could involve exploring spiritual workplace practices in social enterprises (different forms, contexts) in terms of how value is created, as well as what kind of value and for whom. What are some of the ways in which social enterprises that are spiritual could maximize value for all or most stakeholders? How could spirituality protect against social enterprises' mission drift, and vice versa, how could social enterprises guard against the misuse of workplace spirituality? How would a spiritual social enterprise respond to crises and aim to address all or as many goals as possible (social, societal, environmental, and economic)?

\section{Being well (flourishing)}

This aspect can be linked to individual, group, organizational and extra-organizational perspectives. Workplace spirituality (including spiritual leadership) has been associated (mainly from organizational and leader/employee perspectives) with many beneficial outcomes such as high morale, commitment, ethical behaviour and less stress (Fry, 2003; Giacalone \& Jurkiewicz, 2003; Karakas, 2010; McGhee \& Grant, 2017; Mitroff \& Denton, 1999), as well as better leadership, increased creativity and productivity and reduced turnover (Sendjaya, 2007, p. 105). Despite the limitations of these perspectives, the spiritual paradigm is a promising approach for creating better societies by enhancing the well-being of multiple stakeholders (Tencati \& Zsolnai, 2012; Vasconcelos, 2015, 2018).

In most organizational research, the relevance of well-being has been assessed through the perspective of performance and how managers can redesign work practices to support employee and organizational well-being for performance reasons (Grant et al., 2007). In contrast, workplace spirituality scholars address well-being as a valuable outcome in itself (Korac-Kakabadse et al., 2002, McKee et al., 2008, Ungvári-Zrínyi, 2014). Spirituality is seen as part of the eudaimonic approach to well-being (e.g. Van Dierendonck \& Mohan, 2006; Wills, 2009). Eudaimonia is about excellence, human flourishing (for more details see for example Aristotle, 2014) and living life (including work life) in accordance to inner beliefs, values and potentials for achieving worthy goals or making a significant contribution, which gives meaning to one's existence (Van Dierendonck \& Mohan, 2006; Wills, 2009). Similarly, spiritual well-being is a lifelong dedication and attunement with the self, the community, the environment and the sacred (Van Dierendonck \& Mohan, 2006). This means living in harmony and unity with the self, as well as with others. Thus, spirituality includes eudaimonic, pro-other well-being concerns. The 'other' could be understood broadly as humanity, society, the environment and other living beings. 
Social enterprises, likewise, aim to facilitate well-being at various levels. Kauanui et al. (2010) show that spiritually oriented entrepreneurs, as opposed to financially oriented ones, benefit from heightened well-being. Munoz et al. (2015) provide evidence that social enterprise supports both reflective and experiential types of well-being. These authors also state that well-being can be experienced beyond the space of the social enterprise, stemming from the human and social capital development of people and communities. Thus, well-being outcomes transcend social enterprise members and users, or the social enterprise as a whole, and extend to broader communities and to other areas of life. The social value creation can result in personal, mutual or public benefit (Bull \& Ridley-Duff, 2019). Social enterprises, therefore, can have a wider role in supporting flourishing, as they can enhance place-based well-being, as well as contribute to socioeconomic development (e.g. Kay et al., 2016; Munoz et al., 2015). This is similar to the spiritual approach; however, future research could explore these potentials in spiritual social enterprises.

Certainly, the work that organizational members do is not distinct from the rest of their life, and it impacts how individuals understand and express themselves, and how they experience their life as a result of the work they do (Chalofsky, 2003). Beyond the individual level, it is important to consider the wider benefits of the work performed in and for organizations. This is something that workplace spirituality and social entrepreneurship have in common, which is a potential for further study. For instance, how could a balance between giving to self and to others or balancing manifold (often competing) goals be achieved in a spiritual social enterprise?

\section{Conclusion}

Social enterprises offer a work context in which organizational members can reconcile their (spiritual) beliefs with a career in business. This type of work context may alleviate potential tensions that may arise between individual beliefs and what is (seen as) socially acceptable at work. These issues are equally relevant for both individual experiences of well-being at work and collective well-being through creating work that serves people and communities better, thus, generating positive outcomes for the individual, the community and society.

Social enterprises seem to be a promising way of organizing, compared to conventional businesses, due to their ingrained social purpose as part of their business model, rather than just a social responsibility initiative. These contemporary initiatives indicate that today's workforce wants to imbue meaning in organizational life beyond solely pursuing an income. Thus, work becomes more than a source of paycheque: the workplace becomes a space for discovering and constructing the self and an opportunity to serve others. Therefore, social enterprises can be a supportive context for workplace spirituality that aligns the need for value creation with spiritually driven motives (doing good for others). Moreover, workplace spirituality can support the preservation of the integrity of social enterprises' purpose. The spiritual perspective on the understanding of the social enterprise and the complementarity between the two fields could be a promising future research agenda.

This paper has presented the main characteristics of alignment between workplace spirituality and social enterprises based on a review of the literature (although this was not exhaustive). The paper raised questions for further exploration within each aspect of complementarity between workplace spirituality and social enterprise (motives, practices, outcomes). Future studies could thus look at whether - and if so, in what way - social enterprises in different contexts and cultures manifest work spirituality. It would also be relevant to explore spirituality in social enterprises in different industries and sectors. Beyond the motivational aspects, looking into specific practices, ways of organizing and cooperation within and beyond the organization will improve our understanding of the potential implementation of spirituality in social enterprises. Finally, the topic of well-being - for whom and by whom - deserves attention. It would be especially important to include a perspective beyond individual entrepreneurs or leaders such as organizational members in various roles and positions. The voice of the employee is still lacking in the management and organization literature in general, and likewise, in the workplace spirituality and social enterprise research. This perspective could, however, bring invaluable insights.

\section{References}

Aristotle (2014). Nicomachean ethics. (R. Crisp, Trans.). Cambridge, UK: Cambridge University Press.

Ashar, H., \& Lane-Maher, M. (2004). Success and spirituality in the new business paradigm. Journal of Management Inquiry, 13(3), 249-260. https://doi.org/10.1177/1056492604268218

Ashforth, B. E. \& Pratt, M. G. (2003). Institutionalized spirituality: An oxymoron?. In R. A. Giacalone \& C. L. Jurkiewicz (Eds.), Handbook of workplace spirituality and organizational performance (pp. 93-107). New York, NY: Sharpe.

Ashmos, D. P. \& Duchon, D. (2000). Spirituality at work: A conceptualization and measure. Journal of Management Inquiry, 9(2), 134-145. https://doi.org/10.1177/105649260092008

Austin, J., Stevenson, H., \& Wei-Skillern, J. (2006). Social and commercial entrepreneurship: same, different, or both?. Entrepreneurship Theory and Practice, 30(1), $1-22$.

https://doi.org/10.1111/j.1540-6520.2006.00107.x

Avolio, B. J., Gardner, W. L., Walumbwa, F. O., Luthans, F., \& May, D. R. (2004). Unlocking the mask: A look at the process by which authentic leaders impact follower attitudes and behaviors. The Leadership Quarterly, 15(6), 801-823. https://doi.org/10.1016/j.leaqua.2004.09.003

Balog, A. M., Baker, L. T., \& Walker, A. G. (2014). Religiosity and spirituality in entrepreneurship: A review 
and research agenda. Journal of Management, Spirituality \& Religion, 11(2), 159-186.

https://doi.org/10.1080/14766086.2013.836127

Barney, J. B., Wicks, J., Otto S. C., \& Pavlovich, K. (2015). Exploring transcendental leadership: a conversation. Journal of Management, Spirituality \& Religion, 12(4), 290-304.

https://doi.org/10.1080/14766086.2015.1022794

Bell, E., \& Taylor, S. (2003). The elevation of work: Pastoral power and the new age work ethic. Organization, 10(2), 329-349.

https://doi.org/10.1177/1350508403010002009

Benefiel, M. (2005). The second half of the journey: Spiritual leadership for organizational transformation. The Leadership Quarterly, 16(5), 723-747. https://doi.org/10.1016/j.leaqua.2005.07.005

Bouckaert, L. \& Zsolnai, L. (2012). Spirituality and business: An interdisciplinary overview. Society and Economy, 34(3), 489-514.

https://doi.org/10.1556/socec.34.2012.3.8

Bull, M., \& Ridley-Duff, R. (2019). Towards an appreciation of ethics in social enterprise business models. Journal of Business Ethics, 159(3), 619-634. https://oi.org/10.1007/s10551-018-3794-5

Case, P., \& Gosling, J. (2010). The spiritual organization: critical reflections on the instrumentality of workplace spirituality. Journal of Management, Spirituality \& Religion, 7(4), 257-282.

https://doi.org/10.1080/14766086.2010.524727

Chalofsky, N. (2003). An emerging construct for meaningful work. Human Resource Development International, 6(1), 69-83. https://doi.org/10.1080/1367886022000016785

Chell, E., Spence, L. J., Perrini, F., \& Harris, J. D. (2016). Social entrepreneurship and business ethics: Does social equal ethical?. Journal of Business Ethics, 133(4), 619-625. 10.1007/s10551-014-2439-6

Dacin, M. T., Dacin, P. A., \& Tracey, P. (2011). Social entrepreneurship: A critique and future directions. Organization Science, 22(5), 1203-1213. https://doi.org/10.1287/orsc.1100.0620

Defourny, J., \& Nyssens, M. (2017). Fundamentals for an international typology of social enterprise models. VOLUNTAS: International Journal of Voluntary and Nonprofit Organizations, 28(6), 2469-2497. https://doi.org/10.1007/s11266-017-9884-7

Dey, P., \& Steyaert, C. (2010). The politics of narrating social entrepreneurship. Journal of Enterprising Communities: People and Places in The Global Economy, 4(1), 85-108. https://doi.org/10.1108/17506201011029528

Dik, B. J., \& Duffy, R. D. (2009). Calling and vocation at work: Definitions and prospects for research and practice. The Counseling Psychologist, 37(3), 424-450. https://doi.org/10.1177/0011000008316430

Dolan, S. L., \& Altman, Y. (2012). Managing by values: The leadership spirituality connection. People and Strategy, 35(4), 20-27.

Driscoll, C., McIsaac, E. M., \& Wiebe, E. (2019). The ma- terial nature of spirituality in the small business workplace: From transcendent ethical values to immanent ethical actions. Journal of Management, Spirituality \& Religion, 16(2), 155-177.

https://doi.org/10.1080/14766086.2019.1570474

Duffy, R. D., \& Dik, B. J. (2013). Research on calling: What have we learned and where are we going? Journal of Vocational Behavior, 83(3), 428-436. https://doi.org/10.1016/j.jvb.2013.06.006

Fry, L. W. (2003). Toward a theory of spiritual leadership. The Leadership Quarterly, 14(6), 693-727. https://doi.org/10.1016/j.leaqua.2003.09.001

Gamble, E. N., \& Beer, H. A. (2017). Spiritually informed not-for-profit performance measurement. Journal of Business Ethics, 141(3), 451-468.

https://doi.org/10.1007/s10551-015-2682-5

Garcia-Zamor, J. C. (2003). Workplace spirituality and organizational performance. Public Administration Review, 63(3), 355-363.

https://doi.org/10.1111/1540-6210.00295

Gjorevska, N. (2019). Workplace spirituality in social entrepreneurship: Motivation for serving the common good. In L. Bouckaert \& S. van den Heuvel (Eds.), Servant leadership, social entrepreneurship and the will to serve (pp. 187-209). Cham: Springer. https://doi.org/10.1007/978-3-030-29936-1_10

Grant, A. M., Christianson, M. K., \& Price, R. H. (2007). Happiness, health, or relationships? Managerial practices and employee well-being tradeoffs. The Academy of Management Perspectives, 21(3), 51-63. https://doi.org/10.5465/amp.2007.26421238

Green, B. N., Johnson, C. D., \& Adams, A. (2006). Writing narrative literature reviews for peer-reviewed journals: secrets of the trade. Journal of Chiropractic Medicine, 5(3), 101-117. https://doi.org/10.1016/S0899-3467(07)60142-6

Guillén, M., Ferrero, I., \& Hoffman, W. M. (2015). The neglected ethical and spiritual motivations in the workplace. Journal of Business Ethics, 128(4), 803816. https://doi.org/10.1007/s10551-013-1985-7

Haskell, D. L., Haskell, J. H., \& Pottenger, J. J. (2012). Harnessing values for impact beyond profit in MENA. In D. Jamali \& Y. Sidani (Eds.), CSR in the Middle East (pp. 25-48). London, UK: Palgrave Macmillan. https://doi.org/10.1057/9781137266200_3

Houghton, J. D., Neck, C. P., \& Krishnakumar, S. (2016). The what, why, and how of spirituality in the workplace revisited: A 14-year update and extension. Journal of Management, Spirituality \& Religion, 13(3), 177-205. https://doi.org/10.1080/14766086.2016.1185292

Hudson, R. (2014). The question of theoretical foundations for the spirituality at work movement. Journal of Management, Spirituality \& Religion, 11(1), 27-44. https://doi-org.roe.idm.oclc.org/10.1080/14766086.2013.801031

Jurkiewicz, C. L. \& Giacalone, R. A. (2004). A values framework for measuring the impact of workplace spirituality on organizational performance. Journal of Business Ethics, 49(2), 129-142. 
Karakas, F. (2010). Spirituality and performance in organizations: A literature review. Journal of Business Ethics, 94(1), 89-106. https://doi.org/10.1007/s10551-009-0251-5

Karakas, F., \& Sarigollu, E. (2013). The role of leadership in creating virtuous and compassionate organizations: Narratives of benevolent leadership in an Anatolian tiger. Journal of Business Ethics, 113(4), 663-678. https://doi.org/10.1007/s10551-013-1691-5

Kauanui, S. K., Thomas, K. D., Rubens, A., \& Sherman, C.L. (2010). Entrepreneurship and spirituality: A comparative analysis of entrepreneurs' motivation. Journal of Small Business \& Entrepreneurship, 23(4), 621-635. https://doi.org/10.1080/08276331.2010.10593505

Kay, A., Roy, M. J., \& Donaldson, C. (2016). Re-imagining social enterprise. Social Enterprise Journal, 12(2), 217-234. https://doi.org/10.1108/SEJ-05-2016-0018

Kociatkiewicz, J., Kostera, M., \& Parker, M. (2020). The possibility of disalienated work: Being at home in alternative organizations. Human Relations, 2020(April), $1-25$. https://doi.org/10.1177/0018726720916762

Koltko-Rivera, M. E. (2006). Rediscovering the later version of Maslow's hierarchy of needs: Self-transcendence and opportunities for theory, research, and unification. Review of General Psychology, 10(4), 302-317. https://doi.org/10.1037/1089-2680.10.4.302

Korac-Kakabadse, N., Kouzmin, A., \& Kakabadse, A. (2002). Spirituality and leadership praxis. Journal of Managerial Psychology, 17(3), 165-182. https://doi.org/10.1108/02683940210423079

Krishnakumar, S., \& Neck, C. P. (2002). The "what", "why" and "how" of spirituality in the workplace. Journal of Managerial Psychology, 17(3), 153-164. https://doi.org/10.1108/02683940210423060

Lavine, M., Bright, D., Powley, E. H., \& Cameron, K. S. (2014). Exploring the generative potential between positive organizational scholarship and management, spirituality, and religion research. Journal of Management, Spirituality \& Religion, 11(1), 6-26. https://doi.org/10.1080/14766086.2013.801032

Lips-Wiersma, M., Dean, K. L., \& Fornaciari, C. J. (2009). Theorizing the dark side of the workplace spirituality movement. Journal of Management Inquiry, 18(4), $288-300$. https://doi.org/10.1177/1056492609339017

Long, B. S., \& Driscoll, C. (2015). A discursive textscape of workplace spirituality. Journal of Organizational Change Management, 28(6), 948-969. https://doi.org/10.1108/JOCM-12-2014-0236

May, D. R., Gilson, R. L., \& Harter, L. M. (2004). The psychological conditions of meaningfulness, safety and availability and the engagement of the human spirit at work. Journal of Occupational and Organizational Psychology, 77(1), 11-37. https://doi.org/10.1348/096317904322915892

McGhee, P., \& Grant, P. (2017). The transcendent influence of spirituality on ethical action in organizations.
Journal of Management, Spirituality \& Religion, 14(2), 160-178.

https://doi.org/10.1080/14766086.2016.1268539

McKee, M. C., Mills, J. H., \& Driscoll, C. (2008). Making sense of workplace spirituality: Towards a new methodology. Journal of Management, Spirituality \& Religion, 5(2), 190-210.

https://doi.org/10.1080/14766080809518699

Miller, T. L., Grimes, M. G., McMullen, J. S., \& Vogus, T. J. (2012). Venturing for others with heart and head: How compassion encourages social entrepreneurship. Academy of Management Review, 37(4), 616-640. https://doi.org/10.5465/amr.2010.0456

Mitroff, I. I. (2003). Do not promote religion under the guise of spirituality. Organization, 10(2), 375-382. https://doi.org/10.1177/1350508403010002011

Mitroff, I. I., \& Denton, E. A. (1999). A study of spirituality in the workplace. MIT Sloan Management Review, 40(4), 83-92. Retrieved from https://sloanreview.mit.edu/article/a-study-of-spirituality-inthe-workplace/

Munoz, S. A., Farmer, J., Winterton, R., \& Barraket, J. O. (2015). The social enterprise as a space of well-being: an exploratory case study. Social Enterprise Journal, 11(3), 281-302.

https://doi.org/10.1108/SEJ-11-2014-0041

Oswick, C. (2009). Burgeoning workplace spirituality? A textual analysis of momentum and directions. Journal of Management, Spirituality \& Religion, 6(1), 15-25. https://doi.org/10.1080/14766080802648615

Parker, M., Cheney, G., Fournier, V., \& Land, C. (2014). The question of organization: A manifesto for alternatives. Ephemera: Theory and Politics in Organization, 14(4), 623-638.

Pawar, B. S. (2008). Two approaches to workplace spirituality facilitation: A comparison and implications. Leadership \& Organization Development Journal, 29(6), 544-567. https://doi.org/10.1108/01437730810894195

Pawar, B. S. (2009). Some of the recent organizational behavior concepts as precursors to workplace spirituality. Journal of Business Ethics, 88(2), 245. https://doi.org/10.1007/s10551-008-9961-3

Pearce, J. (1994). Enterprise with a social purpose. Town and Country Planning, 63, 84-85.

Pruzan, P. (2008). Spiritual-based leadership in business. Journal of Human Values, 14(2), 101-114. https://doi.org/10.1177/097168580801400202

Reave, L. (2005). Spiritual values and practices related to leadership effectiveness. The Leadership Quarterly, 16(5), 655-687. https://doi.org/10.1016/j.leaqua.2005.07.003

Santos, F. M. (2012). A positive theory of social entrepreneurship. Journal of Business Ethics, 111(3), 335-351. https://doi.org/10.1007/s10551-012-1413-4

Sendjaya, S. (2007). Conceptualizing and measuring spiritual leadership in organizations. International Journal of Business and Information, 2(1), 104-126. https://doi.org/10.6702/ijbi.2007.2.1.5 
Sheep, M. L. (2006). Nurturing the whole person: The ethics of workplace spirituality in a society of organizations. Journal of Business Ethics, 66(4), 357-375. https://doi.org/10.1007/s10551-006-0014-5

Stone, A. G., Russell, R. F., \& Patterson, K. (2004). Transformational versus servant leadership: A difference in leader focus. Leadership \& Organization Development Journal, 25(4), 349-361. https://doi.org/10.1108/01437730410538671

Sullivan Mort, G., Weerawardena, J., \& Carnegie, K. (2003). Social entrepreneurship: Towards conceptualization. International Journal of Nonprofit and Voluntary Sector Marketing, 8(1), 76-88. https://doi.org/10.1002/nvsm.202

Talmage, C. A., Bell, J., \& Dragomir, G. (2019). Searching for a theory of dark social entrepreneurship. Social Enterprise Journal, 15(1), 131-155. https://doi.org/10.1108/SEJ-06-2018-0046

Teasdale, S. (2012). What's in a name? Making sense of social enterprise discourses. Public Policy and Administration, 27(2), 99-119. https://doi.org/10.1177/0952076711401466

Tiba, S., van Rijnsoever, F. J., \& Hekkert, M. P. (2019). Firms with benefits: A systematic review of responsible entrepreneurship and corporate social responsibility literature. Corporate Social Responsibility and Environmental Management, 26(2), 265-284. https://doi.org/10.1002/csr.1682

Tongo, C. I. (2016). Transcendent work motivation: biblical and secular ontologies. Journal of Management, Spirituality \& Religion, 13(2), 117-142. https://doi.org/10.1080/14766086.2015.1086669

Ungvári-Zrínyi, I. (2014). Spirituality as motivation and perspective for a socially responsible entrepreneur- ship. World Review of Entrepreneurship, Management and Sustainable Development, 10(1), 4-15.

https://doi.org/10.1504/WREMSD.2014.058049

Van Dierendonck, D., \& Mohan, K. (2006). Some thoughts on spirituality and eudaimonic well-being. Mental Health, Religion \& Culture, 9(3), 227-238. https://doi.org/10.1080/13694670600615383

Vasconcelos, A. F. (2015). The spiritually-based organization: A theoretical review and its potential role in the third millennium. Cadernos Ebape, 13(1), 183-205. https://doi.org/10.1590/1679-395110386

Vasconcelos, A. F. (2018). Workplace spirituality: Empirical evidence revisited. Management Research Review, 41(7), 789-821.

https://doi.org/10.1108/MRR-07-2017-0232

Waddock, S., \& Steckler, E. (2013). Wisdom, spirituality, social entrepreneurs, and self-sustaining practices: What can we learn from difference makers? In J. Neal (Ed.), Handbook of faith and spirituality in the workplace (pp. 285-301). New York, NY: Springer. https://doi.org/10.1007/978-1-4614-5233-1_18

Wills, E. (2009). Spirituality and subjective well-being: Evidences for a new domain in the personal well-being index. Journal of Happiness Studies, 10(1), 49-69. https://doi.org/10.1007/s10902-007-9061-6

Zaidman, N. (2019). The incorporation of self-spirituality into Western organizations: A gender-based critique. Organization, 27(6), 858-881. https://doi.org/10.1177/1350508419876068

Zsolnai, L. (2011). Moral agency and spiritual intelligence. In L. Bouckaert \& L. Zsolnai (Eds.), Handbook of spirituality and business (pp. 42-48). London, UK: Palgrave Macmillan. 